\title{
The International Specialist Strategy: Financial Funding and Deployment
}

\author{
Briance Mascarenhas \\ Rutgers University, USA
}

Many firms facing global competition are seeking to become specialists. This study examines international specialists, defined as companies that produce, sell, and expand internationally within one industry. This study examines their capital sourcng and deployment. Analysis of a knowledge-intensive industry, pharmaceuticals, suggests that firms which pursue this focused strategy match their funding and deployment of financial resources. They use equity funding and invest it heavily in research in order to develop international proprietary niches.

Keywords: strategy, focus, niche, international, diversification, finance

\section{Introduction}

In this study we examine international specialist firms. These firms produce, sell, and expand internationally within one industry. Macroeconomic trends suggest that this strategy is becoming increasingly common as the fraction of firms that are industrially diversified has declined over time and the fraction of firms with international sales has increased over time (Denis, Denis and Yost, 2002).

Managers may pursue the international specialist strategy for various reasons. They build assets in chosen fields and exploit them internationally, helping to overcome foreign entry barriers. They may expand abroad to capture international growth opportunities, international risk diversification, factor cost differences, and greater market power within their niche. At the same time, by restricting their

(Multinational Finance Journal, 2012, vol. 16, no. 1/2, pp. 87-103)

(C) Multinational Finance Society, a nonprofit corporation. All rights reserved. DOI: $10.17578 / 16-1 / 2-4$ 
industrial scope, they avoid diversification into other industries where they have little relevant expertise and fewer synergies exist. They also avoid possible inefficient allocation of capital across industrial divisions.

International specialists differ from domestic industrially focused firms because of their broader international scope. They also differ from firms that are diversified industrially and internationally because of their narrower industrial scope.

Research suggests that a firm's market valuation is discounted by industrial and international diversification due to inefficient internal capital allocation, coordination difficulties, monitoring and agency costs between managers and investors (Denis, Denis and Yost, 2002). However, international diversification can at times improve market valuation (Doukas and Lang, 2003) if it is based on exploiting intangible capabilities and assets through internalization (Mork and Yeung, 1991).

While the managerial aims and potential investor benefits of international specialist firms are becoming apparent, it is less clear how to develop this strategy. Finance is fundamentally concerned with raising and allocating capital, and underlies all strategies. We do not know how international specialists raise capital and deploy it in order to implement their strategy.

This study of 164 firms based in 24 countries in the pharmaceutical industry examines the capital raising and deployment practices of international specialists. It finds that international specialists adjust and match their capital sourcing and deployment. They tend to utilize equity capital and deploy it in research, reinforcing each other, and encouraging their industrial focus and international expansion.

\section{The Pharmaceutical Industry}

The pharmaceutical industry produces drugs to improve society's health and well-being. The pharmaceutical industry is a large, knowledge-intensive, global industry. The industry has worldwide annual sales of over $\$ 130$ billion and is composed of about 200 firms based in two dozen countries. The industry's environment may be characterized as fine grained, which favors specialist firms, rather than coarse-grained. This environmental granularity and possibility for multiple niches is due to its complexity, presence of generic and 
proprietary drugs, diverse diseases, many development technologies, and several drug delivery methods. Drug development technologies available, for example, are based on modern western science, traditional eastern medicine, biotechnology, combinatorial chemistry, genomics, and robotics. And drug delivery methods include oral, inhalable, and injectable, with differing time releases.

The industry develops treatments for many diseases with varying geographic and socioeconomic contours, using multiple drug development technologies, for patients with differing income levels, in the face of conflicting government policies towards intellectual property rights and pubic access to health care, and rising research costs and cost containment pressures. Industrialized nations support intellectual property rights and patent protection. In contrast, many developing countries are more concerned with public access to medications and so permit product patents but not process patents in order to encourage development of substitute generic drugs. Pharmaceutical firms are facing increased cost-containment pressures to control drug prices from emerging third-party payers such as insurance companies and national governments. Policy-makers, such as the Food and Drug Administration, have been streamlining the drug approval process to permit quicker introduction of new drugs and, as they come off patent, of generics. Prices of generic drugs have been declining over time (Generic..., 1996). The key decision-makers on prescriptions are shifting from individual doctors to third-party payers such as insurance companies (Twomey and Stafford-Sigg, 1997).

The industry's numerous firms differ in their international and industrial scopes, permitting analysis of the international specialist strategy. Some pharmaceutical firms have a domestic scope, such as Mylan Labs, a producer of generic and branded drugs. Other pharmaceutical firms are industrially diversified multinationals, such as Bayer that has activities also in agriculture, coatings and colorants, fibers, and plastics. And still others are industry-focused international firms:

Amgen, a global biotechnology based firm, produces drugs based on advances in cellular and molecular biology. Swiss-based Alcon, spun off from Nestle, dominates the international market for ophthalmic medications and eye care. And Dr. Reddy's Laboratories from India has over 1500 scientists, seven patents including one to treat diabetes, and a presence in over 100 countries (Pilling, 1999b). 


\section{Hypotheses}

We examine factors that encourage the development of both industrial focus and international expansion, or industry-focused firms. In contrast, researchers have typically examined industrial diversification and international diversification as distinct phenomena (Meyer, 2006), rather than examining a particular combination of these two dimensions. And instead of examining a single factor associated with a focused strategy, we consider multiple factors that are consistent with each other.

Hypotheses relate two focal variables, funding type and research, to both industrial focus and internationalization. Firm funding reflects the type (equity or debt) of financial resources raised. Research activities seek to develop knowledge-intensive, proprietary products. Relative to debt, equity financing is consistent with and likely to be used to fund proprietary pharmaceutical research. Pharmaceutical research has a long cycle and aims to generate specialized assets which may be exploited by firms to treat particular diseases. Specialized assets provide limited collateral protection desired by debt holders in case of bankruptcy. Pharmaceutical firms can also utilize promising results in ongoing research to obtain additional equity financing through private and public placements. Thus funding and research activities in the pharmaceutical industry need to be coordinated to create sustained value (Collis and Montgomery, 1995; Teece, Pisano and Shuen,1997; Teece and Pisano. 1998). Other factors, such as firm size, were also considered for inclusion but were not expected to have the desired impacts on both scope dimensions and so were not hypothesized to encourage the development of international specialist firms. Similarly, variables that were not expected to play an important role in a knowledge-intensive industry were not used to develop hypotheses.

\section{A. Funding}

To grow rapidly and gain market share fast, firms need external funding so that they can invest more funds than what they can generate internally. Or they may need financing to bridge the interim between product/market development and future sales. Investments are needed in $\mathrm{R} \& \mathrm{D}$, marketing, or building distribution. New and growing customers may also need to be financed. Thus financing is broadly useful, and the type of financing (debt or equity) pursued will shape a firm's strategy. In particular, we argue below that equity financing will 
encourage firms to focus on one industry and to expand internationally.

Firms may use equity financing for expanding into related areas and debt financing for unrelated diversification (Kochar and Hitt, 1998). Expansion into related areas involves development and application of firm-specific knowledge-intensive assets and synergies to generate competitive advantages. If debt financing were to be used and a bankruptcy occurs, lenders would recover a small portion of their loan from the collateral firm specific assets deployed in related areas. The inability of lenders to control and monitor the specialized activities of the borrowing firm in this situation creates an agency or moral hazard problem (Jensen,1986). Since lenders do not wish to fund highly firm specific assets involved in related areas, the use of equity financing will be preferred in these cases (Balakrishnan and Fox, 1993). Equity holders can monitor and control specialized activities of an industry-focused firm through board governance.

Lenders will be more likely to lend to firms that diversify their business risk by expanding to other industries. Such firms will be perceived to have more stable earnings and will be given higher debt limits. Their higher debt capacity is due to the coinsurance effect arising from uncorrelated cash streams of different business units (Lewellen,1971). This additional debt capacity and higher financial leverage motivate greater industrial diversification (Singh et. al, 2001; Kochar and Hitt, 1998).

Debt financing is not likely to encourage overseas expansion because there are difficulties of contracting for debt internationally. Debt has high international agency costs (the costs of writing debt covenants, monitoring, auditing, language differences, varying legal systems, and different asset structures). So, all things equal, debt is less likely to be used than equity to fund international expansion (Burgman, 1996). Therefore, the use of debt in firms' capital structures may not encourage international expansion (Lee and Kwok, 1988; Burgman, 1996). These arguments lead to the following hypothesis:

Hypothesis 1: In a knowledge-intensive industry, financial leverage will be negatively related to the development of the international specialist strategy.

\section{B. Research}

We argue below that investment in research will encourage firms to focus on one industry and to expand internationally. 
Research intensive firms in the pharmaceutical industry increasingly focus on particular customers/patients in order to study, understand, and conduct clinical trials on existing disease conditions. This research aims to discover and develop new products/processes that will prevent and treat these diseases. This disease expertise and product knowhow can differentiate them from competitors and potentially give them monopoly power in their chosen space. Investment in research may also result in a continuing stream of new products and processes to stay ahead of imitators.

In the face of declining $R \& D$ productivity, pharmaceutical companies have been trying to increase output by increasing efficiency, narrowing focus, and targeting research to specific diseases (Shaywitz and Taleb,2008). Nobel laureate Sir James Black notes that focused R\&D efforts with little outside interference and a long time frame are useful for developing new drugs (Jack, 2009). Jean-Pierre Garnier, the CEO of GlaxoSmithKline, posits that firms need to invest in focused $\mathrm{R} \& \mathrm{D}$, utilizing both internal and external sources of inputs, improving processes such as international clinical trials, building a strong culture of innovation and developing a passion for excellence (Garnier, 2008).

Higher research intensity is likely to encourage an industry focus. Research and development has been linked to industrial focus (Hitt, Hoskisson and Kim, 1997). Firms that make credible strategic commitments to high levels of innovation to excel in that chosen area are likely to be focused (Corts, 2000). Innovative firms may remain narrow while less innovative firms broaden their industrial scope (Rotemberg and Saloner,1994).

Research intensity should also encourage international expansion. Firms expand internationally to leverage their R\&D know-how to geographic areas where a disease is present as well as to amortize their R\&D costs over a wider geographic sales (Caves, 1971, 1982; Horst, 1972). This R\&D based know-how generates new products/processes for foreign multinational companies to differentiate themselves from domestic firms which are more familiar with their local environments.

In the pharmaceutical industry, firms that are research intensive may expand abroad to seize arbitrage opportunities associated with varying regulatory regimes, availability of inputs, and cost structures. They can augment their research expertise by utilizing multiple national drug discovery approaches, such as western scientific methods, eastern medicines' natural compounds, and/ varying expertise found internationally. Firms that are research oriented may also expand abroad 
to conduct clinical trials concurrently to reduce drug development time and cost. These arguments lead to the following hypothesis.

Hypothesis 2: In a knowledge-intensive industry, higher research intensity will be positively related to the development of the international specialist strategy.

\section{Methodology}

The study examines the hypotheses in a knowledge-intensive industry, pharmaceuticals. This analysis allows examining the characteristics of industry-focused firms relative to others while controlling for the industry. The pharmaceuticals industry is fragmented with many distributed players enabling a statistical analysis in a global context.

Personal interviews were conducted with ten executives from pharmaceutical firms and health maintenance organizations as well as physicians. The purpose was to identify industry trends, variables affecting the product and international expansion of firms, relevant variables for inclusion, and interpret the study's findings.

To examine the hypotheses, line of business, financial, product, customer, and international data are needed for numerous firms in an industry. The data come from Worldscope/Disclosure Partners and are compiled by multi-lingual analysts. Worldscope obtains data from firm filings with stock exchanges, government ministries, newspapers, and annual reports to shareholders, and directly from the companies. All data is quality controlled through a series of balance and stress tests and continuously monitored. Data are presented in a unified format that facilitates comparisons across companies and countries. The companies are identified by their SIC codes.

Worldscope discloses data on 199 public and private pharmaceutical firms that are headquartered in 24 industrialized and emerging countries. This rich data allow examination of many industry firms based in multiple countries, providing a richer global picture. Data on firms from multiple countries are useful to examine the effect of the origin of industry-focused international firms and to assess how the findings are sensitive to the international context. In contrast, restricting the study to a sample of multi-industry firms based in one country would not yield these insights and would be subject to a possible single-country bias. 
TABLE 1. Pharmaceutical Firms Studied By Country of Origin

\begin{tabular}{lc}
\hline Home Country & Number of Firms \\
\hline United States & 59 \\
Japan & 44 \\
United Kingdom & 17 \\
France & 11 \\
India & 9 \\
Germany & 7 \\
Switzerland & 7 \\
Italy & 6 \\
South Korea & 6 \\
Sweden & 6 \\
Australia & 4 \\
Canada & 4 \\
Indonesia & 3 \\
Pakistan & 3 \\
Denmark & 2 \\
Norway & 2 \\
South Africa & 2 \\
Chile & 1 \\
China & 1 \\
Finland & 1 \\
Ireland & 1 \\
Israel & 1 \\
Poland & 1 \\
Turkey & 1 \\
Total & 199 \\
\hline
\end{tabular}

Worldscope provides data on sales, whether or not a firm has international sales, SGA expenditures, R\&D expenditures, the number of employees, and a description of its products and customers. The data available cover a ten year period. Table 1 shows the geographic distribution of these firms across the 24 countries.

\section{A. Variables}

The following list of variables, comprising the dependent variable (INDUSTRY-FOCUSED INTERNATIONALFIRM), the hypothesized variables (LEVERAGE, RESEARCH INTENSITY), and control variables (FIRM SIZE, SGA (Selling, General, and Administrative Expenses) INTENSITY, and COUNTRY OF ORIGIN) were defined and measured. Care was taken to use variable measures that utilize data 
that are available and comparable across countries.

Industry-Focus International Firm: Dummy variable equal to 1 if a firm produced and sold only in the 3-digit SIC Code 283 and had international sales, 0 otherwise. SIC code 283 includes medicinal, biological, and diagnostic products. The 3-digit industry classification is sufficiently broad to capture related products, while screening out unrelated diversification. A narrower 4-digit industry classification would have excluded related fields. The measure of international involvement employed is highly correlated to other measures, such as the percentage of international sales or the number of countries which are less observable for firms based in different countries. An entropy measure of diversification that utilizes the number of and distribution of activity across segments/countries was also considered, but not employed because the underlying data was not available for the cross-national firms studied. It was important to study firms based in multiple countries to control for a country's development which turned out to be statistically significant.

Leverage: Ratio of the book values of the firm's debt to total capital. Leverage increases the risk of bankruptcy. Debt holders are interested primarily in the ability to repay the loan and interest, while equity investors are more interested in the growth and profitability potential of the business.

R\&D Intensity: Firm's research and development expenditures divided by sales. Research and development activities help to generate new drugs that are more effective, have fewer side effects, or provide new cures. Stepped up $R \& D$ spending can lead to a broader product line and hasten new product development and market introduction. The successful development of new drugs can help to reduce price competition (Generic...,1996).

Firm Size: is measured by the number of employees. No difference is observed when using the natural log transformation. This variable is included to examine if global focused firms rely on scale economies or abundant resources in their strategy. Larger size implies scale economies in various activities (purchasing, manufacturing, $R \& D$ ). Larger size also provides a firm with greater clout when dealing with larger third-party prescription buyers in the 
pharmaceutical industry. Sales, another common size measure, is in the denominator of the Research and SGA Intensity variables so is not used in order to reduce definitional dependency among independent variables. Assets was not used because it is sensitive to national accounting conventions. No material changes in result are observed when using sales or total assets instead of employees as a measure.

SGA Intensity: Firm's selling, general, and administrative expenses divided by sales. This variable is included because focused firms may emphasize a direct sales force to understand their customers' needs in order to focus their research efforts. They may also use a sales force and promotion to educate and convince customers when launching new products.

Industrialized Country: Dummy variable equal to 1 if a firm is headquartered in an industrialized country (greater than \$9600) defined in the World Development Report (United States, Japan, United Kingdom, France, Germany, Switzerland, Italy, Sweden, Australia, Canada, Denmark, Norway, Finland, or Ireland), 0 otherwise (the remaining countries where pharmaceuticals were headquartered were emerging economies as classified by Hoskisson et. al. (2000). This variable is included to control for possible profile differences between firms based in industrialized and emerging countries. This categorization is based on multiple underlying dimensions of economic, education, and health care development instead of a single continuous measure of per capita income.

\section{Findings}

For the 199 pharmaceutical companies in the sample, there were variable missing values for 35 firms. For the remaining 164 firms, 31 $(19 \%)$ were focused at the 3-digit industry level, or industry-focused international firms. No significant differences were observed in firm size or industrialized country origin between the 35 firms with missing values and the remaining 164 firms analyzed.

Table 2 shows the descriptive statistics and correlation matrix among independent variables that will be used in the multivariate analyses below. Neither the low correlations (all below 0.50) nor the 
TABLE 2. Mean, Standard Deviations, and Pearson Correlations

\begin{tabular}{|c|c|c|c|c|c|c|c|}
\hline & Mean & S.D. & 1. & 2. & 3. & 4. & 5. \\
\hline $\begin{array}{l}\text { 1. INDUSTRY - FOCUSED } \\
\text { INTERNATIONAL FIRM }\end{array}$ & .16 & .36 & & & & & \\
\hline 2. FIRM SIZE & 8815.00 & 18660.00 & .15 & & & & \\
\hline 3. R\&D INTENSITY & 19.22 & 60.53 & .14 & .17 & & & \\
\hline 4. SGA INTENSITY & 30.87 & 14.05 & .13 & .05 & .35 & & \\
\hline 5. LEVERAGE & 58.00 & 103.95 & -.05 & .10 & .05 & .10 & \\
\hline $\begin{array}{l}\text { 6. INDUSTRIALIZED } \\
\text { COUNTRY }\end{array}$ & .84 & .369 & -.15 & .16 & .16 & -.08 & -.14 \\
\hline
\end{tabular}

variance inflation factors (all below 5) suggest the presence of multicollinearity.

To examine the hypotheses, logit analysis was performed with the dependent dummy variable INTERNATIONAL SPECIALIST FIRM. Logit analysis helps to distinguish industry-focused international firms from all other firms. The logit regression is a model used for the prediction of a certain event, in this case the likelihood of a firm being industry-focused and international. This logit analysis helps to identify the profile of focused international firm by examining the impacts of multiple variables jointly. Multiple discriminant analysis, was also considered but not used, since its parameter estimation is less robust under conditions of variable non-normality (Press and Wilson, 1978) and requires additional information on more groups and how they may differ from one another.

The independent variables included were LEVERAGE, R\&D INTENSITY, FIRM SIZE, SGA INTENSITY, and INDUSTRIALIZED COUNTRY. Table 3 reports the standardized coefficients (betas), the coefficient estimates multiplied by the quotient of the independent variable's standard deviation and the dependent variable's standard deviation, that may be compared directly.

\section{A. Funding}

Hypothesis 1 suggests that financial leverage will be negatively related 
TABLE 3. Logit Model Of International Specialist Firms

\begin{tabular}{lc}
\hline $\begin{array}{c}\text { INDEPENDENT } \\
\text { VARIABLES: }\end{array}$ & $\begin{array}{c}\text { Standardized coefficient } \\
(\mathrm{t}-\text { statistic) }\end{array}$ \\
\hline LEVERAGE & $-1.733^{* *}$ \\
& $(-2.39)$ \\
R\&D INTENSITY & $.182^{* *}$ \\
& $(2.17)$ \\
FIRM SIZE & .681 \\
& $(1.49)$ \\
SGA INTENSITY & 1.375 \\
& $(1.52)$ \\
INDUSTRIALIZED & $-1.272^{* * *}$ \\
COUNTRY & $(-5.11)$ \\
Log Likelihood & $-88.435^{* * *}$ \\
\hline
\end{tabular}

Note: * Significant at the .10 level, ** Significant at the .05 level, *** Significant at the .01 level

with the development of the industry-focused international strategy. The findings suggest that financial leverage $(-1.733)$ is negatively related to the development of this strategy, significant at the 0.05 level. Thus the evidence is consistent with Hypothesis 1.

\section{B. Research}

Hypothesis 2 suggests that higher research intensity will be positively related to the development of the industry-focused international strategy. The findings suggest that $\mathrm{R} \& \mathrm{D}$ intensity (.182) is positively related to industry-focused international firms, significant at the 0.05 level. Thus the evidence is consistent with Hypothesis 2.

International specialist firms are not significantly different from other firms in FIRM SIZE (0.681). This contrasts with the pure industrial and international diversification strategies that are associated with larger firm size (Denis et al.,2002). This finding is inconsistent with the view the specialists are driven by scale economies (Krugman, 1981), but consistent with prior research findings that international specialists may be large or small (Mascarenhas, 1999). Israel Makov, CEO of Teva Pharmaceuticals, notes that the firm's global supply network, which is reflected in the firm's international scope, is more 
important for reducing costs than volume economies.

SGA intensity (1.375) does not significantly predict the development of industry-focused international firms. Interviews suggest that industry-focused international firms at times use the sales forces of their partners when entering foreign countries, rather than their own sales force.

The findings suggest that international focused firms make up a smaller proportion of firms based in developed countries than in emerging countries $(-1.272)$. This may possibly be due to the younger firms found in emerging countries that have not yet had as much time to diversify industrially and to the more mature of stage of the industry when specialist firms in emerging countries are likely to arise. By implication, restricting the study to firms from one country would likely bias the coefficient estimates.

\section{Sensitivity analysis}

Tests were performed to assess the robustness of the findings against other possible explanations. Since the high research intensity of focused firms in the pharmaceutical industry may have been due to the higher research intensity of this industry relative to others, we included dummy variables for other industries in which a firm may participate. We also included a dummy variable for a firm's country of origin. Interactions between size and leverage were also analyzed. No material changes were observed.

\section{Conclusion}

Firms may cope with increasing global competition by repositioning into niches. There is a macroeconomic trend among firms towards greater industrial focus and increased internationalization (Denis, Denis and Yost, 2002). Industrial focus and international diversification, that constitute the international specialist strategy, can at times improve a firm's market valuation (Doukas and Lang, 2003). But this valuation improvement is not automatic and the financial decisions that are needed to implement this strategy are not clear. This study examined this strategy's sourcing and deployment of financial resources. The study finds that in order to implement the international specialist strategy, firms need to adjust and coordinate their sourcing and 
deployment of financial resources.

In financial sourcing, firms that access equity capital are more likely to become industry-focused international firms. Equity is likely to be used to fund assets that are specific to a single industry, because it does not have the agency costs and does not require the collateral protection of debt capital. Equity is also more likely to fund international firm expansion because it does not have the high international monitoring and transaction costs of cross-border debt.

In deploying financial resources, investment in research helps to develop expertise on particular diseases and improve products/processes that better satisfy patient needs. These specialized assets may generate customer value and, if proprietary, also competitive advantages. These specialized assets facilitate international expansion through internalization and give firms an edge over domestic firms when entering foreign markets. Industrial diversification and international diversification have been found to discount a firm's market valuation (Denis, Denis and Yost, 2002). But if international diversification is based on intangible assets developed through research and transferred overseas through internalization, it may actually improve a firm's valuation.

Further, equity financing and investment in research are consistent with and reinforce each other. Equity financing does not have the agency/monitoring costs of debt that would be problematic for developing specialized assets through research.

In summary, the international specialist strategy requires adjusting and coordinating the sourcing and deployment of financial resources. A strategy is more comprehensive and less imitable if it is based on multiple, coordinated activities.

The study has implications for managers. Managers trying to cope with increasing global competition face the challenges of identifying and building a viable niche. The findings suggest a type of focused strategy that they should consider. The findings also suggest that they should adjust and coordinate their decisions involving financial sourcing, towards equity, and financial deployment, towards research.

These findings can be useful to public policy makers and managers because firms have not always been matching their financial funding and deployment because of institutional reasons or managerial choice. Despite their technical innovation and acumen, new firms in Germany are being stifled by their traditional use of conservative debt capital because of the paucity of private equity capital and the recent collapse 
of the Neuer Stock Market for small firms (Germany's, 2006). In contrast, Denmark based NovoNordisk A/S is an international specialist that focuses on the treatment of diabetes in 180 countries. It matches a strong balance sheet with heavy investment in a rigorous $R \& D$ program targeting diabetes (Kam, 2011).

The study's findings expand our understanding of international diversification. Prior research suggests that international diversification destroys value unless it is based on intangible assets. This study's findings suggest that raising equity capital and deploying it in research may create proprietary knowhow that is exploited through internalization when a firm expands abroad, creating sustained value.

This study examined the international specialist strategy. It found that equity financing and research intensity help to pursue this strategy. As data become available, future research should probe deeper into types of equity financing and types of research activities which are supportive. For example, research can be conducted internally or through the use of collaborations, or the firm can invest large funds in few projects or spread their resources over many projects which give them long run development options. The findings may be relevant to other fine-grained, knowledge-intensive industries. Research is needed in coarse grained environments and less knowledge-intensive industries in order to compare the findings. Future research needs to also uncover and examine other types of focused firms, such as those with a regional focus. These efforts will increase our understanding of the diverse strategies in the global economy and provide managers insights to make strategic choices to deal with international competition.

Accepted by: Prof. P. Theodossiou, Editor-in-Chief, October 2011

\section{References}

Balakrishnan, S., and I. Fox I. 1993. Asset specificity, firm heterogeneity, and capital structure. Strategic Management Journal, 14, 1, 3-16.

Burgman, T. 1996. An empirical examination of multinational capital structure. Journal of International Business Studies, 27: 553-570.

Caves, R.E. 1971. The industrial economics of foreign investment. Economica, 38, 149, 1-27.

Caves, R.E. 1982. Multinational Enterprise and Economic Analysis. Cambridge, MA, Cambridge University Press.

Collis, D. J. and Montgomery, C. Competing on Resources, Harvard Business 
Review, July-August 1995, 118-128.

Comment, Robert and Gregg A. Jarrell 1994. Corporate Focus And Stock Returns. Journal of Financial Economics. 37(1): 67-87.

Corts, K.S. 2000. Focused firms and the incentive to innovate. Journal of Economics and Management Strategy, Vol.9, 3, Fall, 339-362.

Denis, D. J.; Denis, D.K.; and Yost, K. 2002. Global diversification, industrial diversification, and firm value, Journal of Finance, 57, 5, October. 1951-1979.

Doukas, J.A., and Lang, L. 2003. Foreign Direct Investmet, and Firm Performance. Journal of International Business Studies, 34,2,153-172.

Garnier, J.P. 2008. Rebuilding the R\&D engine in big pharma. Harvard Business Review, May.

Generic pharmaceutical prices continue their decline in prices from last year. 1996. Hospital Materials Management, 21 (2), February, 1,12.

Germany's new breed of serial entrepreneur. 2006. FT.com, 18:27, March 27.

Hitt, M.A.; Hoskisson, R.E.; and Kim, H. 1997. International diversification: effects on innovation and firm performance in product-diversified firms. Academy of Management Journal. Vol. 40, 4, 767-798.

Hoskisson, R.E.; Eden, L.; Lau, C.M.; and Wright, M. 2000. Strategy in emerging economies. Academy of Management Journal, Vol. 43, 3, p.249-268.

Horst, T. 1972. Firm and industry determinants of the decision to invest abroad: an empirical study. Review of Economics and Statistics, 54, 28-65.

Jack, A. 2009. An acute talent for innovation. FT.com. February 1, 16, 27.

Jensen, M. C. 1986. Agency costs and free cash flow, corporate finance, and takeovers, American Economic Review, 76, 323-329.

Kam, K. 2011. The oracle of Manitoba is buying. Forbes.com. September 1.

Kochar, R., and Hitt, M.A. 1998. Linking corporate strategy to capital structure: diversification strategy, type, and source of financing. Strategic Management Journal, Vol.19, 6, June, 601-610.

Krugman, P.R. 1981. Intraindustry specialization and the gains from trade. Journal of Political Economy, October, 89, 5, 959-973.

Lee, K., and Kwok, C.C.Y. 1988. Multinational corporations versus domestic corporations: international environmental factors and determinants of capital structure, Journal of International Business Studies, 19: 195-217.

Lewellen, W.G. 1971. A pure financial rationale for the conglomerate merger. Journal of Finance, 26 (2): 521-537.

Mascarenhas, B. 1996. The founding of specialist firms in a global fragmenting industry. Journal of International Business Studies, Vol. 27, 1

Mascarenhas, B. 1999. The strategies of small and large international specialists. Journal of World Business, 34, 3, Autumn, 252-266.

Meyer, K. E. 2006. Globalfocusing: from domestic conglomerate to global specialist, Journal of Management Studies, Vol. 43, 5, July, 1109-1144.

Mishina, Y.; Pollock, T.G.; and Porac, J.F. 2004. Are more resources always 
better for growth? Resource stickiness in market and product expansion. Strategic Management Journal 25: 1175-1197.

Morck, R., and Yeung, B. 1991. Why investors value multinationality. Journal of Business, 64, 2, 165-187.

Pilling, D. 1999b. Drug group fights for market share. Financial Times. July 16, 1999, 17.

Press, J., and Wilson, S. 1978. Choosing between logistic regression and discriminant analysis. Journal of the American Statistical Association. 73, 364, December, 699-705.

Rotemberg, J., and Saloner, G. 1994. Benefits of narrow business strategies. American Economic Review, 84, 5, 1330-1349.

Shaywitz, D., and Taleb, N. 2008. Drug development needs serendipity. FT.Com, July 29, 2008. 19:42.

Singh, M.; Mathur, I.; Gleason, K.C.; and Etebari, A. 2001. An empirical examination of the trend and performance implications of business diversification. Journal of Business and Economic Studies, Vol. 7, 2, Fall 2001, 25-51.

Teece, D.J.; Pisano, G.; and Shuen, A. 1997. Dynamic Capabilities and Strategic Management. Strategic Management Journal, 18 (7): 509-534.

Teece, D.J., and Pisano, G. 1998. The Dynamic Capabilities of Firms: An Introduction, in Technology, Organization, and Competitiveness: Perspectives on Industrial and Corporate Change, Dosi, G.; Teece, D.J.; and Chytry, J. eds., New York: Oxford University Press: 193-212.

Twomey, M., and Stafford-Sigg, E. 1997. Strategic trajectories. Pharmaceutical executive. 17(5), May, 78-90.

World Development Report. 2000. World Bank, Washington, D.C.

Zahra, S.; Ireland, R.D.; and Hitt, M.A. 2000. International Expansion by new venture firms: international diversity, mode of market entry, technological learning and performance. Academy of Management Journal, October, Vol. $43,5,925-951$. 